\title{
Beyond the Fiscal Compact: How Well-Designed Eurobonds May Discipline Governments
}

\author{
by Jakob de Haan, Niels Gilbert, Jeroen Hessel and Silvie Verkaart
}

This contribution argues that despite some progress, primarily via the "Fiscal Compact", more delegation of fiscal sovereignty is needed in order to put the Euro area on a more stable footing. Enforcement of European budgetary rules should be delegated to a fully independent authority. However, enforcement can be strengthened further by introducing well-designed Eurobonds. Eurobonds provide an answer to fundamental problems that the recent crisis in the Euro area revealed: the possibility of speculative attacks. Since Eurobonds are thought to weaken the incentives for fiscal discipline, they should be issued centrally under the condition that Member States no longer be allowed to issue debt independently. A European budgetary authority will distribute the necessary funding only if Member States can prove their adherence to sustainable fiscal policies as defined in the Maastricht Treaty or to the implementation of a strictly monitored adjustment programme. These measures should be sidelined by a banking union and a stricter control of macroeconomic imbalances.

Trotz einiger Fortschritte im Rahmen des "Fiskalpakts" verbleibt noch deutlicher Handlungsbedarf in Fragen haushaltspolitischer Zusammenarbeit in der Eurozone. Zunächst sollte der Vollzug europäischer Haushaltsregeln auf eine unabhängige Behörde übertragen werden. Die damit verbundene Überwachung kann zudem durch sinnvoll angelegte Eurobonds ergänzt und die Währungsunion damit weiter stabilisiert werden, zumal so ein in der aktuellen Krise hervortretendes Problem nachhaltig vermieden werden könnte: spekulative Angriffe auf die Staatsschuld einzelner Mitgliedstaaten. Da Eurobonds aber auch die Haushaltsdisziplin zu untergraben drohen, sollten sie nur unter der Bedingung ausgegeben werden, dass auf mitgliedstaatlicher Ebene von individueller Verschuldung abgesehen wird. Eine europäische Haushaltsbehörde stimmt einer Mittelvergabe nur dann zu, wenn die Maastricht-Kriterien erfüllt sind oder der Mitgliedstaat sich einem rigorosen Anpassungsprogramm unterzieht. Diese Maßnahmen sollten durch eine Bankenunion und eine engmaschigere Überwachung gesamtwirtschaftlicher Ungleichgewichte ergänzt werden.

\section{Introduction}

Monetary unions require restrictions on the fiscal policies of their Member States for several reasons. One important reason is that unsustainable fiscal policies of

The views expressed in this contribution do not necessarily reflect the views of De Nederlandsche $\operatorname{Bank}(D N B)$. 
individual countries in the Economic and Monetary Union (EMU) may undermine financial stability in the Euro area and affect the policies of the European Central Bank (ECB). As Eijffinger and de Haan wrote a long time ago: "Suppose that the government of a country in the Euro area gets into fiscal trouble, from which it cannot extricate itself. Investors fear suspension or (more likely) modification of payment on its public debt, and therefore sell their bonds. Consequently, bond prices start to plummet. Banks holding those bonds find their capital impaired, inciting depositor runs. Bond markets (and indirectly banks) in other EMU countries suffer adverse repercussions, as investors in public debt of other European states become demoralised. To prevent the collapse of Europe's banking and financial system, the ECB therefore has to buy up the bonds of the government in distress." 1 The high levels of exposure that national banks, insurers and pension funds have to both the government and the private (financial) sectors of other Euro area Member States considerably increase these risks. That is one of the reasons why the no-bailout rule proved to be unenforceable. If one country were to default, there would be serious implications for the financial stability of the whole Euro area, because domino effects within the financial sector could mean that one Member State's problems are ultimately transmitted to all the others. Because of these external effects, national fiscal policies cannot be left entirely to the discretion of the Member States.

So for good reasons, the Maastricht Treaty and the Stability and Growth Pact (SGP) as adopted in 1997 stipulate that Euro area Member States have the obligation to avoid excessive government deficits (based on a deficit criterion and a debt criterion, which are assessed against the reference values of 3 per cent and 60 per cent of GDP, respectively). The SGP contains a preventive and a corrective arm. The preventive arm prescribes the path for sound fiscal policies, while the corrective arm (the Excessive Deficit Procedure, or EDP) is intended to ensure the correction of excessive deficits in case they do occur. In the original SGP, only the latter ultimately provided for financial sanctions in case of noncompliance with Council recommendations.

However, the SGP has been severely criticised mainly for its lack of automaticity and weak enforcement. For instance, de Haan et al. argue that "the major problem of the SGP is its weak enforcement mechanisms. ... In our view, reform of the Pact should aim at stricter, instead of more flexible, rules and should not rely 
on cyclically adjusted deficit estimates." ${ }^{2}$ Likewise, Amtenbrink and de Haan pose that "the analysis of the current system presented hereafter suggests that those elements of economic co-ordination which prevent the existing rules from being implemented properly should be amended, thereby to some extent depoliticising economic co-ordination."3

Because of the politicised approach taken to enforce the SGP (combined with the national deficit bias and the lack of market discipline), many Euro area Member States did not start from solid budgetary positions at the outset of the financial crisis in 2008/09. This was an important (but not the only) cause of the subsequent European sovereign debt crisis, and therefore clearly underlines that budgetary discipline should be enhanced.

In this contribution we argue that the Fiscal Compact as recently agreed upon by most EU Member States is a step forward in enhancing fiscal discipline in the Euro area for two reasons. First, it entails fiscal adjustment rules and these rules will be enshrined in national law. There is evidence suggesting that Euro area Member States with national fiscal rules had more disciplined fiscal policies than those without. Second, under the Fiscal Compact, the Euro area Member States will at each stage of the EDP support the European Commission's proposals or recommendations in the Council if a Euro area Member State has an excessive deficit, unless a qualified majority votes against such measures. In practice, this means that reverse qualified majority voting (RQMV) applies to all stages of the EDP, thereby to some extent reducing the discretionary powers of the Council. Despite our moderate optimism, we also argue that more delegation of fiscal sovereignty is needed. Our preferred long-term solution would be to delegate the enforcement of European budgetary rules to a fully independent budgetary authority.

Such an independent authority would be another major step forward. However, we will argue that this independent enforcement can be strengthened further by introducing well-designed Eurobonds. Of course, the desire for fiscal discipline is in itself not a sufficient reason for a proposal as far-reaching as Eurobonds. If lack of fiscal discipline was the only problem in the Euro area, it could and should simply be restored by introducing very strong enforcement mechanisms.

2 De Haan, J./Berger, H./Jansen, D.: Why has the Stability and Growth Pact Failed?, in: International Finance, 7/2 (2004), 235-260, 236.

3 Amtenbrink, F./de Haan, J.: Economic governance in the European Union - Fiscal policy discipline versus flexibility, in: Common Market Law Review, 40 (2003), 1075-1106, 1077. 
Yet Eurobonds provide an answer to another problem that the recent crisis in the Euro area revealed: the possibility of speculative attacks on debt of individual Euro area Member States. The crisis has shown that a system, in which government debt is financed at the national level while countries share a common currency, is inherently unstable. EMU Member States do not have their own monetary policies or exchange rates so that a crisis cannot be (temporarily) alleviated by reducing interest rates or by devaluing the currency. Nor can National Central Banks of the Member States provide their governments with infinite liquidity in a crisis by buying government bonds. These circumstances lead to a situation where concerns about a country may become self-fulfilling prophecies, as uncertainty about the ability to service debts lead to higher rates of interest and thus ultimately to insolvency. Because all Euro area Member States are vulnerable to these processes, financial turmoil in one country can easily spread to other countries.

While Eurobonds may be an effective way to prevent the inherent instability in the Euro area, they are very controversial. ${ }^{4}$ The key reason is that Eurobonds are thought to fundamentally weaken the incentives for fiscal discipline. First, Member States are not exposed to the discipline of financial markets anymore, that however imperfect - provides a strong incentive to prevent or correct unsustainable fiscal policies. Second, Member States know that if they are not able to repay their debt, other countries will be liable for their obligations. We argue, however, that Eurobonds can be designed in a way that strengthens rather than weakens fiscal discipline namely by introducing centrally issued Eurobonds for the full debt, under the condition that Member States will no longer be allowed to independently raise funds in the money or capital markets. An independent budgetary authority will distribute the necessary (Eurobond) funding to the Member States, but only if they have sustainable fiscal policies as defined in the Maastricht Treaty or implement a strictly monitored adjustment programme.

Even then, the full mutualisation of risks with regard to government debt of individual Member States is only sustainable if accompanied by other, much stronger safeguards to prevent that these budgetary risks arise in Member States, such as a banking union with strong European supervision, and a stricter enforcement of rules to prevent macroeconomic imbalances. In addition, Member

4 Issing, O.: Why a common Eurozone bond isn't such a good idea, in: Europe's World, summer 2009, 76-79. 
States should first reduce their debt to a much lower level than is currently the case, which implies that Eurobonds as proposed by us cannot be used as a crisis instrument.

This contribution is structured as follows. The next section explains why the SGP has failed (II.). Section III. shows that the Fiscal Compact is to be considered as a major step in the right direction, whereas section IV. offers a sketch of our preferred long-term solution. This is followed by a brief conclusion.

\section{Why the Stability and Growth Pact failed}

Under the preventive arm of the SGP, Member States submit stability or convergence programmes in which they detail their medium-term budgetary plans. Under the original SGP, Member States were required to pursue the mediumterm objective of budgetary positions that were "close to balance or in surplus". There was, however, no possibility to impose sanctions on Member States violating Commission recommendations.

The Excessive Deficit Procedure (EDP) is the corrective arm of the SGP. When the ECOFIN Council, based on a proposal of the European Commission, decides that an excessive deficit exists in a Member State, the procedure provides for a sequence of steps to be taken that should intensify the pressure on the Member State concerned to take effective action to correct its excessive deficit. For each step, the ECOFIN has to take decisions on the basis of recommendations or proposals by the Commission. If a Member State does not take (sufficient) action to redress an excessive deficit, sanctions may be imposed. Sanctions include the requirement for the Member State concerned to make a non-interest bearing deposit, which, if non-compliance persists, is eventually turned into a fine.

Critics of the SGP pointed to a major weakness of the rules in place: the ECOFIN will not automatically impose sanctions, as each step requires a discretionary decision by the Council. And the same ministers who are responsible for drafting national budgets and who may therefore be accused of breaking the rules also have to decide whether one of their colleagues breaches the same rules. Credible rules need an impartial, consistent and competent enforcement mechanism. The SGP rules are enforced in the end by the ECOFIN, which "manifestly does not have the collective capacity to commit itself to an impartial, consistent enforcement of the rules". 5 There are no strong incentives for Member States to 
prevent other Member States from deviating from the objective to strive for a balanced budget in the medium term. Furthermore, the Member States have no other means than peer pressure in the multilateral surveillance part of the SGP. No wonder, therefore, that several Member States did not adhere to this mediumterm objective. Large countries, in particular, did not bring down their deficit sufficiently. ${ }^{6}$ As a consequence, they exceeded the 3 per cent deficit threshold once the economic downturn set in after 2000/2001. Subsequently, it became clear that the enforcement mechanism in the excessive deficit procedure is also weak.

The amendments of the SGP as introduced in 2005 brought even more discretion and flexibility into the corrective arm, although the preventive arm became slightly more stringent. ${ }^{7}$ As to the latter: each Member State will present its own country-specific medium-term objective (MTO) in its stability programme. These country-specific MTOs will be differentiated and may diverge from the "close to balance or in surplus" requirement depending on the current debt ratio and potential growth. The adjustment effort should be greater in good times and could be more limited in bad times. As a benchmark, the Member States should pursue an annual adjustment in cyclically adjusted terms, net of one-off and temporary measures, of 0.5 per cent of GDP.

Under the revised EDP, when assessing and deciding upon the existence of an excessive deficit, the Council can consider an excess over the reference value resulting from a severe economic downturn as exceptional if the excess over the reference value results from a negative growth rate or an accumulated loss of output during a protracted period of very low growth relative to potential growth. When evaluating whether a Member State's deficit exceeds the 3 per cent limit, the Commission has to take into account numerous factors related to the development of the medium-term economic position, such as the implementation of the policies in the context of the Lisbon agenda, policies to foster research, development and innovation, fiscal consolidation efforts in economic 'good times', debt sustainability, public investment, financial contributions to international solidarity, fiscal burdens related to European unification, pension reforms and the overall quality of public finances.

7 Amtenbrink, F./de Haan, J.: Reforming the Stability and Growth Pact, in: European Law Review, 31/3 (2006), 402-413. 
The SGP did not succeed in maintaining fiscal discipline in most Euro area Member States. In periods with above-trend growth, fiscal policies were not sufficiently adjusted to achieve sustainable budgetary positions. Violations of the deficit criterion were not sufficiently corrected. In addition, the debt criterion was largely ignored. This is highly problematic as the Euro crisis stemmed principally from doubt regarding the (future) serviceability of government debts. It is therefore vital that Euro area Member States bring their debt positions under much stricter control, and subsequently maintain that control. A sustainable currency union requires that the level of debt should be sufficiently low so that, even in the event of a deep recession, the situation does not become unsustainable. This may require substantial buffers vis-à-vis the thresholds for the deficit and the debt in the Maastricht treaty. Gilbert and Hessel show that the financial crisis caused a budgetary deterioration that was much larger than what was foreseen when the existing budgetary rules in EMU were designed. ${ }^{8}$ Government debt has, for instance, grown substantially in most Euro area Member States since 2007 (cf. figure 1), notably so in Portugal, Ireland, Greece and Spain, where the debt ratio has increased by an average of 51 per cent of GDP. ${ }^{9}$

\section{Figure 1: Growth in Government Debt since the Start of the Credit Crisis}

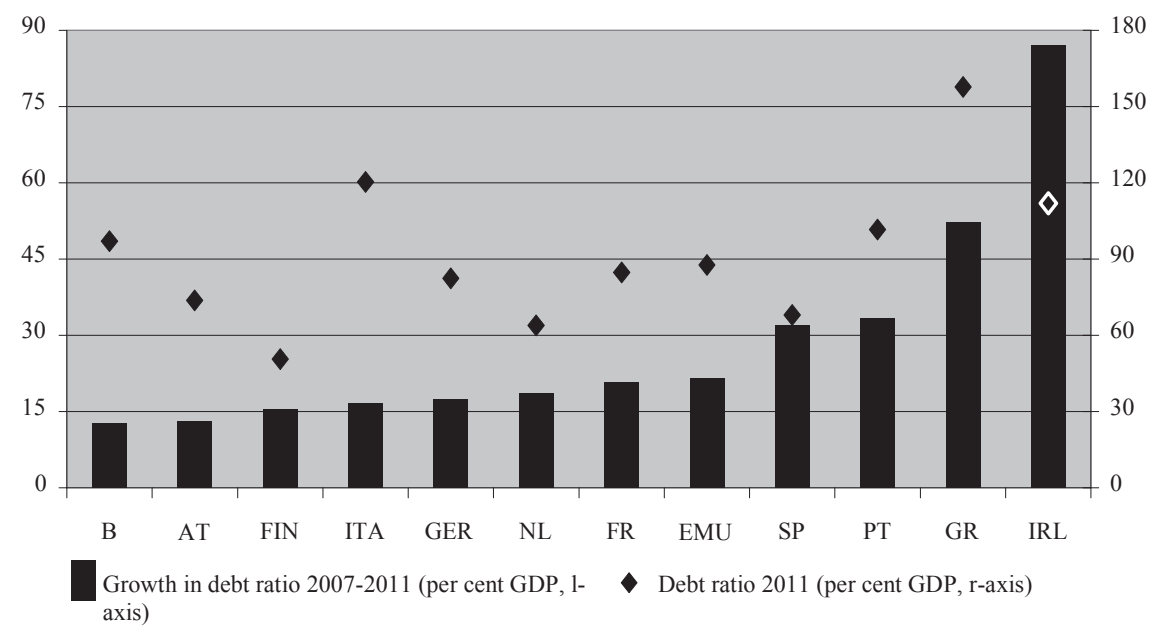

8 Gilbert, N.D./Hessel, J.P.C.: De Europese Overheidsfinanciën Tijdens de Crisis (European Public Finances during the Crisis), in: Economisch Statistische Berichten, 97, 166-169, 2012.

9 Part of this deterioration is to be attributed to the rescue packages for the banking sector, particularly in Ireland and Spain. It is, however, primarily due to the deep and prolonged recession and/or the lack of structural capacity for growth in these countries. 
The most important reason why the SGP failed "was that the SGP was implemented half-heartedly as enforcement of the fiscal rules through peer pressure was weak. The procedures for addressing non-compliance lacked automaticity and thus left too much room for discretion. Financial sanctions have, in fact, never been imposed." 10

\section{Six-pack and Fiscal Compact}

In view of the compelling need for a reform of the fiscal policy governance framework in the Euro area, European policy makers have taken several steps, including the introduction of the six-pack and the Treaty on Stability, Coordination and Governance in the Economic and Monetary Union (TSCG). Fear that the sovereign debt crisis would spread further, thereby undermining the stability of the Euro area and perhaps even the sustainability of the currency union, created the political willingness to take these steps.

The so-called six-pack, consisting of five Regulations and one Directive, entered into force on 13 December 2011. It does not only cover fiscal policy surveillance, but also macroeconomic surveillance under the new Macroeconomic Imbalance Procedure. In the fiscal field, the six-pack reinforces both the preventive and the corrective arm of the SGP. For instance, it defines quantitatively what a 'significant deviation' from the MTO or the adjustment path towards it means in the context of the preventive arm. Moreover, the six-pack enables that an EDP may be launched if a country does not meet the rule for the government debt ratio (i.e. the ratio is above 60 per cent of GDP and does not diminish towards the Treaty reference value at a satisfactory pace). Financial sanctions are imposed in a gradual way, from the preventive arm to the latest stages of the EDP, and may eventually reach 0.5 per cent of GDP.

Most importantly, the six-pack introduces reverse qualified majority voting (RQMV) for decisions on most sanctions. RQMV implies that a recommendation or a proposal of the Commission is considered adopted by the Council unless a qualified majority of Member States votes against it, thereby bringing some automaticity in the procedure and making it more likely that sanctions will be imposed.

10 European Central Bank: A Fiscal Compact for a Stronger Economic and Monetary Union, in: ECB Monthly Bulletin, May 2012, 79-94, 81. 
Despite some improvements, the ECB identifies several weaknesses of the reinforced SGP. ${ }^{11}$ There are, for instance, still too many exceptional situations that can be taken into account when deciding on whether a deficit or debt-to-GDP ratio is excessive. As a result, non-compliance with the deficit or debt criterion will not necessarily result in the launch of an excessive deficit procedure. More importantly, the reinforced SGP still lacks sufficient automaticity in case of noncompliance with the rules as the Council continues to take most decisions on a discretionary basis. For example, the Council has to decide by qualified majority that an excessive deficit exists. As decisions have to be taken on the basis of a proposal or recommendation of the Commission, the effectiveness of the reinforced SGP also still depends heavily on a strict and rigorous application of the rules by the Commission.

On 2 March 2012, the Heads of State or Government of all EU Member States, except the United Kingdom and the Czech Republic, signed the Treaty on Stability, Coordination and Governance in the Economic and Monetary Union (TSCG), which will enter into force after twelve Euro area countries have ratified it. The articles in Title III of the Treaty referring to fiscal policy are also known as the "Fiscal Compact". The two most important elements are a balanced budget rule, including an automatic correction mechanism, and a strengthening of the excessive deficit procedure.

The contracting parties commit to implementing in their national legislation a fiscal rule, which requires the general government budget to be in balance or in surplus. This rule requires that the annual structural balance should be in line with the country-specific MTO with a lower limit of a structural deficit of 0.5 per cent of GDP. This limit is 1 per cent if the government debt-to-GDP ratio is significantly below 60 per cent and risks to long-term fiscal sustainability are low. As pointed out by the ECB, in practice the new balanced budget rule will not be more ambitious than the EU regulation already demands, since all Euro area Member States currently have an MTO that equals a structural deficit of 0.5 per cent of GDP or less. ${ }^{12}$

The balanced budget rule must include a correction mechanism, which is automatically triggered in the event of significant observed deviations from the MTO or the adjustment path towards it (with escape clauses for exceptional circum- 
stances ${ }^{13}$ ). Under the Fiscal Compact there should be "rapid convergence" to the MTO, but the time frame is still to be specified in a proposal by the Commission. The Commission has also been given the task of proposing common principles for the correction mechanism.

More importantly, the balanced budget rule must be introduced in the national law of the countries concerned within one year after the TSCG enters into force. This must be done in a binding and permanent way, preferably at the constitutional level. The European Court of Justice (ECJ) may impose a financial sanction ( 0.1 per cent of GDP) if a country does not properly implement the new budget rules in national law and fails to comply with a ECJ ruling that requires it to do so.

Recently, Frankel and Schreger have examined fiscal policy outcomes in 24 countries, focusing on forecasts errors. ${ }^{14}$ They find that governments' budget forecasts are biased in the optimistic direction, notably so in Euro area Member States, especially when they have large budget deficits. If Euro area governments do not have an excessive deficit at the time forecasts are made, their forecasts are no more biased than those of other countries. However, if Euro area Member States exceed the 3 per cent cap on budget deficits, they almost never forecast that they will violate the cap in the coming years. ${ }^{15}$ Interestingly, Frankel and Schreger find that Euro area Member States without national budget balance rules have a larger over-optimism bias. In other words, national fiscal rules help counteract wishful thinking in fiscal policy. When governments are in violation of the 3 per cent cap the national rules apparently constrain them from making unrealistic forecasts.

The Fiscal Compact also strengthens the Excessive Deficit Procedure of the SGP, in particular by increasing its automaticity if a Euro area Member State is in breach of the deficit criterion. Most importantly, at each stage of the Excessive

13 The definition of these exceptional circumstances is the same as in the preventive arm of the SGP.

14 Frankel, J.A./Schreger, J.: Over-optimistic Official Forecasts in the Eurozone and Fiscal Rules, NBER Working Paper No. 18283, 2012

15 In related work (Beetsma, R./Giuliodori, M./Wierts, P.: Planning to Cheat: EU Fiscal Policy in Real Time, in: Economic Policy, 24/60 (2009), 753-804), it was found that realized budget balances among SGP countries on average fall short of official ex ante plans. A subsequent study (Beetsma, R./Bluhm, B./Giuliodori, M./Wierts, P.: From First-Release to Ex-Post Fiscal Data: Exploring the Sources of Revision Errors in the EU, CEPR Discussion Paper No. 8413, 2012) then decomposed the overall optimism bias in the budget forecasts of EU governments into the component that arises between initial plans and the first release of actual budget numbers and the component that arises between the first release and the final revised budget numbers. 
Deficit Procedure Euro area Member States will support the Commission's proposals or recommendations in the Council if a Euro area Member State is in breach of the deficit criterion, unless a qualified majority of them is against it. In practice this means that if a Euro area Member State breaches the deficit criterion, reverse qualified majority voting applies to all stages of the EDP. The introduction of this voting commitment for important procedural steps, such as the opening of an excessive deficit procedure, the decision whether a Euro area Member State has taken effective action, and a possible stepping-up of the excessive deficit procedure, increases the automaticity of procedures compared to the reinforced SGP. ${ }^{16}$

Unfortunately, reverse qualified majority voting will not be applied following a breach of the debt criterion by a Euro area Member State. It seems that European policy makers still have to learn the lesson from the sovereign crisis that debt levels are more important than deficits when it comes to the sustainability of the currency union. Furthermore, as pointed out by the ECB, for the new rules to work it is crucial that the Commission uses its increased influence by taking a rigorous approach when assessing fiscal deficits and avoids politically influenced decisions. $^{17}$

Even though we consider the Fiscal Compact a step in the right direction, it does not sufficiently redress all the shortcomings of the SGP identified earlier. Furthermore, "its effectiveness and credibility remains subject to a strict implementation of fiscal policy surveillance by the Commission and a limited use of political discretion by the Council". ${ }^{18}$ That is why we argue in favor of further steps curtailing national fiscal sovereignty.

\section{Further steps: Eurobonds only and an independent fiscal au- thority}

Our preferred long-term solution would be to delegate the enforcement of European budgetary rules to a fully independent budgetary authority. Such an independent authority would be another major step forward. Well-designed Eurobonds can strengthen this independent enforcement. These Eurobonds should 
therefore not be seen as a short-term solution and issuing them should, in our view, not be seen as a crisis instrument. ${ }^{19}$

Several economists and politicians have argued in favour of the introduction of Eurobonds. Eurobonds are understood here as centrally-issued, jointlyguaranteed bonds for financing the Euro area Member States' public debt. By sheltering Euro area Member States from the financial markets, Eurobonds potentially reduce the risk of speculative attacks. Several authors have therefore argued that the introduction of Eurobonds would help stabilise the EMU. ${ }^{20}$ However, sheltering countries from financial markets obviously has a flip side: market discipline is taken away, too. Together with the fact that other Euro area countries explicitly assume liability for other countries' debt, this creates moral hazard: countries lose the incentive to take care of their public finances.

Multiple authors have taken up the task of finding an ideal compromise between stabilizing EMU and limiting moral hazard. One of the most elaborate proposals to date is the 'Blue and Red Eurobond' proposal by Delpla and von Weizsäck$e r .{ }^{21}$ Under this proposal, Member States would divide their sovereign debt into two parts. The first part, up to the debt limit of 60 per cent of GDP, should be pooled as 'blue bonds' with senior status. This debt would be jointly and severally guaranteed by participating countries. Thus, each country, each year, would guarantee all the blue debt of all other participating countries to be issued the following year. The blue debt would thus be the senior tranche of the sovereign debt of the countries in the Euro area. All debt beyond the 60 per cent threshold consists of 'red bonds' with junior status by the Member States themselves. Red bonds could never be guaranteed by another country and could not be bailed out by EU mechanisms (European Financial Stability Mechanism (EFSM), European Financial Stability Facility (EFSF), or the European Stability Mechanism (ESM)). The annual allocation of blue bonds would be proposed by an independent Stability Council to be voted upon by the national parliaments of the participating countries, having the ultimate budgetary authority required to issue the blue bond mutual guarantees.

19 For a further elaboration of the case for Eurobonds, cf. Hessel, J.P.C./Gilbert, N.D./Verkaart, S.A.M.: Towards a Sustainable Monetary Union: What Role for Eurobonds?, DNB working paper, forthcoming.

20 Cf., among others, De Grauwe, P.: The Governance of a Fragile Eurozone, CEPS Working Document No. 346, May 2011; Boonstra, W.W.: Can Eurobonds Solve EMU's Problems?, Rabobank Working Paper August 2011.

21 Delpla, J./von Weizsäcker, J.: The Blue Bond Proposal, Bruegel Policy Brief 03, 2010; ibid.:, Eurobonds: The Blue Bond concept and its implications, Bruegel Policy Contribution, 2011/2. 
In this proposal, some market discipline is retained because governments can only finance part of their debt with Eurobonds (that is, if the "no bail-out clause" in this proposal turns out to be more credible than the original no bail-out clause). This also implies that speculative attacks remain possible; that is: it remains possible for countries to lose access to debt financing against reasonable rates. Steinkamp and Westermann argue that the increasing share of loans with preferred creditor status (such as official aid packages) is one of the factors driving up interest rates on sovereign debt for Euro area Member States. ${ }^{22}$ This implies that proposals such as the introduction of blue bonds could even increase the risk of financial market turbulence.

Several other proposals try to mitigate moral hazard by restricting the availability of Eurobonds to certain maturities or by introducing Eurobonds only temporari$1 y .^{23}$ These proposals face similar trade-offs as the Blue-Red Bond proposal. Besides retaining a limited form of market discipline, all these Eurobond proposals do relatively little to strengthen budgetary discipline. This is a consequence of the fact that countries are still allowed to borrow themselves.

We will argue that a better position is achievable along this trade-off, by designing Eurobonds in a specific way that strengthens rather than weakens fiscal discipline. We argue that Eurobonds can only be an effective instrument if accompanied by two measures. First, it is essential that countries can no longer enter the capital and money markets on their own initiative. This implies a complete centralization of debt issuance in the Euro area accompanied by a common liability for that debt. Second, an independent budgetary authority has to be created with powers to enforce fiscal adjustments in Member States if they have unsustainable fiscal policies.

It could be argued that the proposed scheme also implies that financial markets can no longer enforce fiscal discipline. Market discipline is the reason why in the Maastricht Treaty the principle of debt financing at market conditions was introduced into primary union law. Yet, financial markets arguably do not have a very good track record in enhancing fiscal discipline, ${ }^{24}$ making this a much less seri-

22 Steinkamp, S./Westermann, F.: On Creditor Seniority and Sovereign Bond Prices in Europe, Institute of Empirical Economic Research Working Papers No. 92, Osnabrück, 2012..

23 ELEC: Euro T-Bill Fund - A proposal for a two-year refinancing for all $€$ bills/optional refinancing of bond maturities until 2015, 27 January 2012; Philippon, T./Hellwig, C.: Eurobills, not Eurobonds, VoxEU online, 2 December 2011; Sachverständigenrat: A European Redemption Pact, Vox-EU online, 9 November 2011.

24 Favero, C.A./Missale, A.: EU Public Debt Management and Eurobonds, European Parliament, 2010. 
ous drawback. A more serious objection against the introduction of Eurobonds, even if they fully replace national bonds, is that a moral hazard problem occurs as a Member State may be tempted to free ride on other Members' legal obligations to assume its debt in case of default. It is for this reason that a centralized 'blue bonds only' scheme will have to include measures to effectively and credibly enforce fiscal discipline. Put differently, the introduction of such blue bonds only will not suffice to ensure fiscal discipline.

Therefore we argue in favour of an independent Budgetary Authority, which not only issues Eurobonds but can also intervene if a Member State has too high a level of debt. The authority's independence should be constitutionally embedded similar to what can be found for the independence of the ECB. What is more, the authority's mandate needs to be as clear as possible not least to allow for a meaningful accountability of this body. One option could be: ensure that government debt remains below the ceiling of 60 per cent of GDP in all individual Euro area Member States. The authority's governing board should include budgetary experts and decisions should be made on the basis of simple majority voting or, in certain special circumstances, qualified majority voting. This would lead to much more decisive governance in times of crisis than the current decision-making by the Council of the European Union. Moreover, the Budgetary Authority needs to have the exclusive authority over the granting of loans to Member States.

As long as they do not exceed the debt ceiling, Member States retain full autonomy to determine the size, composition and financing of their national budgets. The debt ceiling should be enforced by placing Member States exceeding the ceiling it in a form of receivership. Such countries would be temporarily allowed to take on extra debt (not on their own, but via the Budgetary Authority), under the strict condition that they adhere to a budgetary correction programme. A Member State would be allowed to define the programme itself, subject to feasibility and efficacy review by the authority. If the corrections proposed by the debtor nation were insufficient, the Authority would be able to impose corrections. Any country that failed to satisfy the requirements would be denied access to additional finance and would therefore have no choice but to immediately take further austerity measures. In a system where Eurobonds would be the sole finance vehicle, such a sanction would be much more credible than anything that is currently imposed on problem countries, because countries would have no access to finance except via the new Budgetary Authority. At the same time, if the Member States adhere to the adjustment programme, there would be no question of (re)financing existing debt. 


\section{Conclusions}

The sustainability of a monetary union requires restrictions on national fiscal policy of the Member States. This principle was recognised in the Maastricht Treaty but not put into practice due to several shortcomings of the Stability and Growth Pact, both in its initial form as well as after some changes were introduced in 2005. Its most severe shortcomings are its politicised and discretionary decision-making procedure as well as lack of effective instruments to discipline governments. Although the six-pack and the Fiscal Compact redress some of these shortcomings, the new fiscal governance rules in place are not sufficient to maintain fiscal discipline. More delegation of fiscal sovereignty is needed, and our preferred long-term solution would be to delegate the enforcement of European budgetary rules to a fully independent budgetary authority. Such an independent authority could be strengthened even further by introducing welldesigned Eurobonds, i.e. centrally issued Eurobonds for the full debt under the condition that Member States will no longer be allowed to independently raise funds in the money or capital markets. The independent budgetary authority only distributes funds to Member States if they have sustainable fiscal policies as defined under the SGP or if they properly implement a strictly monitored adjustment programme. Not only will such a system impose fiscal discipline, collective financing based on Eurobonds will also prevent speculative attacks on debt of individual Euro area Member States as occurred during the recent crisis in the Euro area.

Finally, we want to stress that our proposal is not a short-term solution and we do not favour issuing Eurobonds as a crisis instrument. The full mutualisation of risks with regard to Member States' government debt is only sustainable if accompanied by other safeguards to prevent that these budgetary risks arise, such as a banking union with strong European supervision, and a stricter enforcement of rules to prevent macroeconomic imbalances. In addition, Member States should first reduce their debt towards a much lower level than is currently the case. In fact, it would be risky to introduce Eurobonds early as a crisis measure without first making the necessary but time-consuming treaty amendments to ensure that national government finances are organised on a sound basis. Early introduction might lead to the treaty provisions being unduly loose, because of the immediate danger having been removed by the arrival of Eurobonds. 